Legalization, and finally John Keown reflects upon the Dutch experience, concluding that the legal and medical criteria for in Holland 'would not appear to constitute an effective safeguard against the practice of non-voluntary and involuntary euthanasia'.

Overall this volume is a valuable contribution to the debate about euthanasia. Both the 1982 report and the 1993 submission contain powerful arguments against legalising euthanasia and, whilst representing a particular perspective, are valuable resources for all who seek to inform themselves on this controversial and important issue.

DR KRISTINA STERN Lecturer in Law, School of Law and Centre of Medical Law and Ethics, King's College, London

\section{Advance directives and the pursuit of death with dignity}

Norman L Cantor, Bloomington and Indianapolis, Indiana University Press, 1993, 209 pages, $£ 22.50$

This book, by a distinguished American lawyer, is a welcome addition to the growing literature on end-of-life issues. At one level it is a well-articulated polemic for its author's convictions: the desirability of written advance instructions about one's wishes, coupled with the appointment of an agent to interpret them and ensure their implementation. Although we are told that in a pluralistic society there are almost no moral precepts, Cantor's essay is an exploration and defence of 'prospective autonomy'. This, at least, a pluralistic society should, he thinks, accept. But it would be unfair to represent his book as a campaign for it is also a wideranging survey of legal, moral and practical issues. As such, it deserves to be read by anyone with an interest in terminal care.

Cantor sees the best legal realisation of his convictions in the Advance Directives for Health Care Act (1991) adopted in New Jersey. Accordingly, a chapter is devoted to this legislation and the New Jersey Bioethics Commission's Combined Health Advance Directive (AD) is printed as one of the valuable appendices. Individual documents are likely to have a low take-up and the case is argued for a standard format. Even here he concedes that the problems arising from a conflict of the incompetent patient's contemporaneous wellbeing and the advance instructions cannot be definitely resolved. His fear is that unless such legislation can be made to work pressure for euthanasia and assisted suicide will increase perhaps a bad thing, although he never actually says so.

The difficulty with all this, as he concedes, is the reluctance most of us have to confront our own mortality. How many readers of this review have written an $A D$ ? Even in the USA, the best estimates are 5-25 per cent, mostly in inadequate shortform formats. The $\mathrm{AD}$ is likely to remain a minority interest and even if its operation were problem-free, it is hard to see how it would prevent 'reliance from prior general interactions' that seem to Cantor 'quite unsound'. If an $\mathrm{AD}$ is really necessary to secure 'a modicum of dignity in the dying process', the prospects for many of us are unappealing. But is it necessary? The link made in the book's title needs a fuller exploration.

The differences between states and between state and federal law become apparent early in the book, illustrated by the Cruzan case. Cantor goes on to discuss statutory frameworks, their drafting and interpretation. $\mathrm{He}$ suggests that a health care provider should, and could, be compelled to violate his or her conscience where alternative arrangements to accom-m modate the patient could not be $\overrightarrow{\text {. }}$. made. This is highlighted in his resolution of five scenarios. If the doctors $\Rightarrow$ won't implement the $\mathrm{AD}$, why notes? 'sue them to hell'? To this we have theo lame reply that litigation would prob-등 ably be expensive, exhausting and $\overline{\bar{N}}$. frustrating. I thought this a weakness. $\overline{\mathbb{\phi}}$ In his highly individualistic emphasis on autonomy, Cantor fails to explores adequately the effects of one person's decisions on others. Families and:doctors have their own moral posi- $\vec{\omega}$ tions that may go beyond an emo- $\odot$ tional inability to cope with prospective death or 'good medical: practice'. Nurses in particular often express strong views about withdrawali of nutrition. This deserves a fuller $\vec{\sim}$ moral analysis than we are offered.ळ But these are minor points. Cantor writes clearly and avoids excessiverepetition. I warmly recommend his $D$ book.

JOHN SAUNDERS Consultant Physician, $₫$ Nevill Hall Hospital, , Abergavenny, Wales

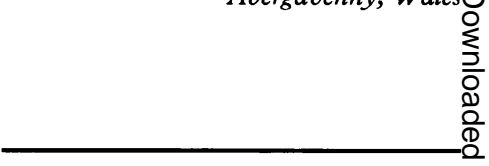

Books: information and orders

If you wish to order or require further? information regarding the titleso reviewed here, please write to on telephone the BMJ Bookshop, PO Box 295, London WC1H 9JR. Tel: $: 0$ 071383 6244. Fax: 0713836662.3 Books are supplied post free in the UK and for BFPO addresses. Overseas customers should add $15^{\mathcal{2}}$ per cent for postage and packing. 금 Payment can be made by cheque in $>$ sterling drawn on a UK bank or by을. credit card (Mastercard, Visa, or American Express, stating card number, expiry date, and full name (TheN price and availability are occasionally N subject to revision by the publishers) 